UDC 331.453:613.155:697.953:[519.6:004.94]

\author{
M. M. BILIAIEV ${ }^{1 *}$, S. G. TSYGANKOVA ${ }^{2 *}$ \\ ${ }^{1 *}$ Dep. «Hydraulics and Water Supply», Dnipropetrovsk National University of Railway Transport Named \\ after Academician V. Lazaryan, Lazaryan St., 2, Dnipropetrovsk, Ukraine, 49010, tel. +38 (056) 37315 09, \\ e-mail gidravlika2013@mail.ru, ORCID 0000-0002-1531-7882 \\ ${ }^{2 *}$ Dep. «Water Supply, Drainage and Hydraulic», Pridneprovsk State Academy of Civil Engineering and Architecture, \\ Chernyshevskyi St., 24-a, Dnipropetrovsk, Ukraine, 49600, tel. +38 (050) 69792 18, e-mail s-tsygankova@mail.ru, \\ ORCID 0000-0002-9837-3109
}

\title{
COMPLEX OF NUMERICAL MODELS FOR COMPUTATION OF AIR ION CONCENTRATION IN PREMISES
}

Purpose. The article highlights the question about creation the complex numerical models in order to calculate the ions concentration fields in premises of various purpose and in work areas. Developed complex should take into account the main physical factors influencing the formation of the concentration field of ions, that is, aerodynamics of air jets in the room, presence of furniture, equipment, placement of ventilation holes, ventilation mode, location of ionization sources, transfer of ions under the electric field effect, other factors, determining the intensity and shape of the field of concentration of ions. In addition, complex of numerical models has to ensure conducting of the express calculation of the ions concentration in the premises, allowing quick sorting of possible variants and enabling «enlarged» evaluation of air ions concentration in the premises. Methodology. The complex numerical models to calculate air ion regime in the premises is developed. CFD numerical model is based on the use of aerodynamics, electrostatics and mass transfer equations, and takes into account the effect of air flows caused by the ventilation operation, diffusion, electric field effects, as well as the interaction of different polarities ions with each other and with the dust particles. The proposed balance model for computation of air ion regime indoors allows operative calculating the ions concentration field considering pulsed operation of the ionizer. Findings. The calculated data are received, on the basis of which one can estimate the ions concentration anywhere in the premises with artificial air ionization. An example of calculating the negative ions concentration on the basis of the CFD numerical model in the premises with reengineering transformations is given. On the basis of the developed balance model the air ions concentration in the room volume was calculated. Originality. Results of the air ion regime computation in premise, which is based on numerical 2D CFD model and balance model, are presented. Practical value. A numerical CFD model and balance model for the computation of air ion regime allow calculating the ions concentration in the premises in the conditions of artificial air ionization taking into account the main physical factors determining the formation of ions concentration fields.

Keywords: air ions regime; concentration field of air ions, artificial ionization; CFD model; balance model

\section{Introduction}

In recent years in field of labor protection considerable attention is paid to the observance of the appropriate qualitative air composition in premises, as evidenced by the increased number of publications, both domestic and foreign scientists on this problem. Since to support air ion regime use often artificial ionization of the air, it is necessary calculate quickly the ions concentration anywhere in the premises. Thus it is necessary to take into account the geometric characteristics of the premises, placement therein of furniture and equipment, the presence dust sources, the aerodynamics of the air jets in the room, the interaction of different polarities ions with each other and with dust particles etc. In addition to the aforesaid, there is need to develop methods for express calculation of the ions concentration in the premises, allowing quick sorting variants and enabling the «integrated» evaluation of the ions concentration in the premises.

Currently in Ukraine are used mainly analytical models [5-13] for computation air ion concentration in premises. As a rule, these models do not consider the presence of equipment, furniture, dust emission sources, physical factors influencing the formation of ions concentration field. To take into account these factors, it is expedient to use CFD models $[2-4,15,18]$. For a quick evaluation of the ions concentration in the premises can be used the balance models [2-4, 15, 18]. 


\section{Purpose}

The purpose of this work is to develop complex of numerical models to calculate the ions concentration field at using artificial ionization of air to support air ion regime in the premises.

\section{Methodology}

In this paper, two numerical models to calculate the concentration of ions in the premises were proposed.

The first model. To calculate the ions concentration in the premises 2D CFD model, which is based on the mass transport, aerodynamics and electrostatics equations, is proposed. This model is developed taking into account physical factors that influence the formation of ions concentration field. Also at modeling the geometric characteristics of premises, placement of furniture and equipment, presence of dust emission sources, the interaction of different polarities ions with each other and with dust particles is taken into account. In view of the aforesaid at the modeling of ions dispersion process, transport equation will have the form [18]:

$$
\begin{aligned}
\frac{\partial C}{\partial t}+ & \frac{\partial(u+b E) C}{\partial x}+\frac{\partial(v+b E) C}{\partial y}= \\
= & \frac{\partial}{\partial x}\left(\mu_{x} \frac{\partial C}{\partial x}\right)+\frac{\partial}{\partial y}\left(\mu_{y} \frac{\partial C}{\partial y}\right)-\alpha C B- \\
& -\beta C D+\sum Q_{c}(t) \delta\left(x-x_{c}\right) \delta\left(y-y_{c}\right),
\end{aligned}
$$

where $C, B, D-$ is the concentration of negative and positive air ions and dust particles respectively; $u, v,-$ velocity components of airflow in the room; $\mu=\left(\mu_{x}, \mu_{y}\right)$ - diffusion coefficients; $t-$ time; $\alpha$-recombination rate of ions with different polarity; $\beta-$ the recombination rate of ions with dust particles; $Q_{C i}-$ the intensity of the negative ions emission at the appropriate points with the coordinates $x_{c}, y_{c} ; \delta\left(x-x_{i}\right) \delta\left(y-y_{i}\right)-$ Dirac delta function; $b$ - coefficient of ion mobility; $E$ - electric field intensity.

Since air ions have a charge, they generate an electric field $E$, which is described by the following equation [18]:

$$
\frac{\partial E_{x}}{\partial x}+\frac{\partial E_{y}}{\partial y}=\frac{q_{e}}{\varepsilon_{0}},
$$

here $\varepsilon_{0}-$ is the dielectric permittivity; $q_{e}-$ is the space charge density.

From equation (2) can go to the scalar potential, taking into account such dependence

$$
\begin{aligned}
& E_{x}=-\frac{\partial \phi}{\partial x} \\
& E_{y}=-\frac{\partial \phi}{\partial y} .
\end{aligned}
$$

Then we get the Poisson equation of the following form [18], which we will be used to simulate the electric field:

$$
\frac{\partial^{2} \phi}{\partial x^{2}}+\frac{\partial^{2} \phi}{\partial y^{2}}=-\frac{q_{e}}{\varepsilon_{0}},
$$

here $q_{e}=-e C(x, y), C(x, y)-$ is the concentration of negative air ions; $\phi-$ scalar potential; $e-$ elementary charge. On the basis of this equation is a performed simulation of the electric field.

To describe the processes of positive ions and dust dispersion we will use the equation of transfer in the form [18]:

$$
\begin{aligned}
\frac{\partial B}{\partial t}+\frac{\partial u B}{\partial x}+ & \frac{\partial v B}{\partial y}=\frac{\partial}{\partial x}\left(\mu_{x} \frac{\partial B}{\partial x}\right)+ \\
+ & \frac{\partial}{\partial y}\left(\mu_{y} \frac{\partial B}{\partial y}\right)-\alpha C B-\beta B D+ \\
& +\sum Q_{B}(t) \delta\left(x-x_{B}\right) \delta\left(y-y_{B}\right),
\end{aligned}
$$

$$
\begin{aligned}
\frac{\partial D}{\partial t}+\frac{\partial u D}{\partial x} & +\frac{\partial v D}{\partial y}= \\
= & \frac{\partial}{\partial x}\left(\mu_{x} \frac{\partial D}{\partial x}\right)+\frac{\partial}{\partial y}\left(\mu_{y} \frac{\partial D}{\partial y}\right)+ \\
+ & \sum Q_{D i}(t) \delta\left(x-x_{D}\right) \delta\left(y-y_{D}\right) .
\end{aligned}
$$

Designation of the physical parameters in these equations is the same, which was given for the equation (1).

To calculate the aerodynamics of air flow in the room a model of potential flow will be used. In this case the Laplace equation for the velocity potential 
is a modeling equation

$$
\frac{\partial^{2} P}{\partial x^{2}}+\frac{\partial^{2} P}{\partial y^{2}}=0
$$

where $P-$ is velocity potential.

The components of the air environment velocity vector are connected with the velocity potential following dependencies

$$
\begin{aligned}
& u=\frac{\partial P}{\partial x}, \\
& v=\frac{\partial P}{\partial y} .
\end{aligned}
$$

Formulation of boundary conditions for the modeling equations is considered in $[1,15,18]$.

For the numerical integration of the transfer equations $[1,12,15,18]$ is used the implicit alternately - triangular difference schemes, which has being implemented by the method of running accounts [1]. For the numerical solution of the Laplace equation and Poisson's equation the Liebmann method is used. The calculation is performed on rectangular difference grid.

On the basis of the difference schemes was designed the software package (code) «ION-2». This package is built on a modular principle; each subprogram implements a specific numerical integration of the modeling equation and implementing appropriate boundary conditions.

A feature of the modeled process is the presence of furniture in the room, i.e., objects, influencing the formation of ion concentration field. To «reproduce» these and other objects in the numerical model one uses a technology called «porosity technique», also called the method of marking [1]. The essence of this technology lies in the encoding of difference cells, which belong to such facilities, and the implementation of them in the appropriate boundary conditions.

The second model. For the deduction of express method of the ions concentration computation in the premises the following equation will be used:

$$
\begin{aligned}
\frac{d n}{d t}=q_{n}(t)-\alpha n p & -\beta n A+ \\
& +n_{0}(t) \frac{Q(t)}{V}-n \frac{Q(t)}{V}-\lambda_{i} n
\end{aligned}
$$

$$
\begin{aligned}
\frac{d p}{d t}=q_{p}(t)-\alpha & n p-\beta p A+ \\
& +p_{0}(t) \frac{Q(t)}{V}-p \frac{Q(t)}{V}-\lambda_{i} n
\end{aligned}
$$

here $q_{n}, q_{p}$ are the generation rate of negative and positive ions in the room accordingly; $n_{0}, p_{0}$ are the negative and positive ion concentrations external to the room; $\alpha-$ is the recombination rate of ions with those of opposite polarity; $\beta$ - is the rate of combination of ions with dust particles; $A$ - is dust concentration; $V$ - volume; $Q$ - ventilation rate; $\lambda_{i}-$ the electrostatic deposition of ions.

To describe the dust mass transport equation the equation of the form is used [14]:

$$
\frac{d A}{d t}=q_{A}(t)+A_{0}(t) \frac{Q(t)}{V}-A \frac{Q(t)}{V}-\lambda_{p} n
$$

here $q_{A}$ is the generation of particles in the space; $A_{0}$ is the external particle concentration; $\lambda_{p}-$ the electrostatic deposition of dust particles.

In contradistinction to the classical model Mayya Y. [14] in the equations (9) - (11) takes into account the dependence on time of negative and positive ions emission and dust emission in the premises and the time dependence of the air exchange rate. The system of the given equations closes by setting the initial conditions of the form

$$
A(t=0)=A_{0}, n(t=0)=n_{0}, p(t=0)=p_{0} .
$$

These conditions define the initial values of dust, negative and positive ions concentration, respectively, before the ionization of the air in the premises. It should be noted that the equations (9) - (11) define the concentration of negative and positive ions and dust are not in the room, but on the exit of it. This is defined by the condition that is the deduction of the balance ratios.

Parameter $\lambda_{i}$ can be defined under equation:

$$
\lambda_{i}=\frac{b}{\varepsilon_{0}}\left(q_{e}+q_{c} e A\right)
$$

where $b-$ is the ion mobility; $\varepsilon_{0}$ is the permittivity of free space, $q_{e}$ - the space charge density, which can be expressed as 


$$
q_{e}=e n-e p
$$

here $e-$ is the elementary charge.

The electrostatic deposition of dust $\lambda_{p}$ can be defined under formula

$$
\lambda_{p}=\frac{D_{p}}{D_{i}} q_{c} \lambda_{i}
$$

where $D_{p}$ and $D_{i}$ are the dust and ion diffusion coefficients accordingly; $q_{c}-$ is the characteristic number of charges.

The characteristic number of charges can be found from the expression:

$$
\begin{gathered}
q_{c}=\frac{4 \pi \varepsilon_{0} d_{p} k T}{e^{2}} \times \\
\times\left[\ln \left[1+\frac{d_{p} c p e^{2} t}{4 \varepsilon_{0} k T}\right]-\ln \left[1+\frac{d_{p} c n e^{2} t}{4 \varepsilon_{0} k T}\right]\right]
\end{gathered}
$$

where $k$ is the Boltzmann constant; $T$ is the absolute temperature; $c$ is the thermal speed of the ions $; d_{p}$ is the dust particle diameter; $t$ is the time.

However, following [14], the summands $\lambda_{p}$, $\lambda_{i}$ can be omitted.

The balance equation (9) - (11) is numerically solved by using Euler's method.

For a numerical calculation of the equations (9) - (11) developed a program BALANCE-1 is realized in FORTRAN. For practical use of the program must be set: the premises volume; air exchange rate; concentrations of negative and positive ions and dust, which flows into the premises; the intensity of negative and positive ions emission and dust emission in the premises.

\section{Findings}

The first model. CFD numerical model was used to calculate the ions concentration field in the premises volume at the conditions of artificial air ionization by setting the ionizer indoors.

Sketch of the computational domain is shown in Fig. 1. It is the premises where the air flows enter through the ventilation system. The air exit from the room occurs through the outlet in the wall. The work area includes table and chair placed next. Placement of ionizer was shown in Fig. 1, pos. 5. The intensity of the negative ions emission from the ionizer is $1.3 \times 10^{11} \mathrm{particles} / \mathrm{s}$.

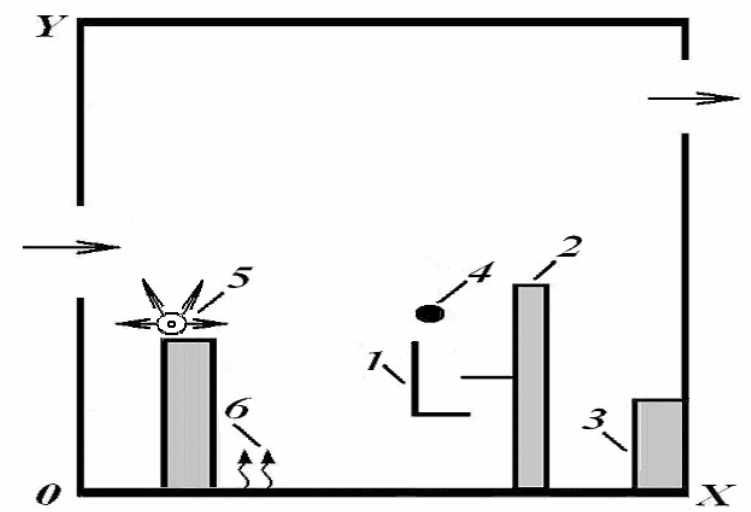

Fig. 1. The computational domain (before reengineering):

1 - chair; 2 - work desk; 3 - rack;

4 - place of positive ions emission (the position of the respiratory organs); 5 -ionizer; 6 - place of dust emission

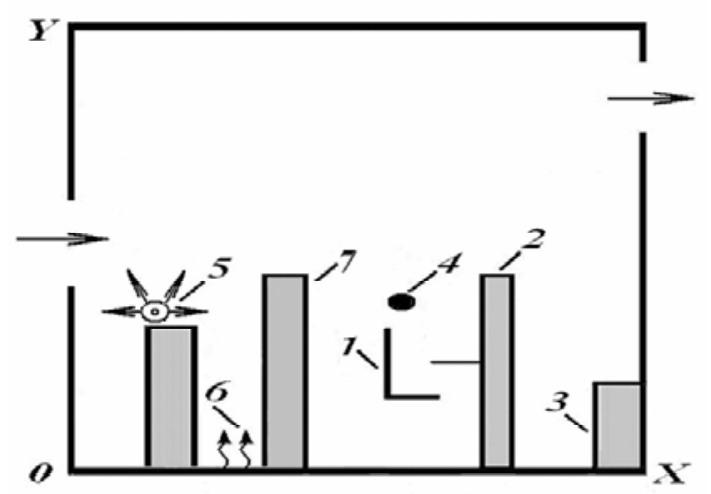

Fig. 2. The computational domain (after reengineering):

1 - chair; 2 - work desk; 3 - rack;

4 - place of positive ions emission

(the position of the respiratory organs); 5 -ionizer; 6 - place of dust emission; 7 - cupboard

The people are the source of positive ions emission in the room. Therefore in the zone of their respiratory organs (Fig. 1, pos. 4) set point sources of positive ions emission intensity $Q_{B}=7 \times 10^{4}$ particles/s. The other of the problem parameters are: the size of the computational domain $7.25 \mathrm{~m} \times 4.20 \mathrm{~m}$; the position of the inlet and outlet ventilation holes is shown by arrows in Fig. 1; $\alpha=$ $1.5 \times 10^{-12} \mathrm{~m}^{3} / \mathrm{s}, \beta=1 \times 10^{-12} \mathrm{~m}^{3} / \mathrm{s}[15,18]$; the coefficients of turbulent diffusion in all directions are 
taken to equal $\mu_{x}=\mu_{y}=k V$ (where $k=0,1-$ the parameter, $V$ - the local velocity in the specific computational point and it is defined by solving the aerodynamic problem). Dust emission occurs indoor, $Q_{D_{i}}=45 \times 10^{4}$ particles $/ \mathrm{s}$ (dust emission position shown in Fig. 1 and Fig. 2 as a wavy line).

Sketch of the same premises where the rearrangement of the furniture is made, was shown in Fig. 2.

Purpose of numerical modeling is definition of the negative ions concentration in the room and the area of the human respiratory system.

The results of numerical simulation in the following figures are shown. On these figures the negative ions concentration field in the room was given.

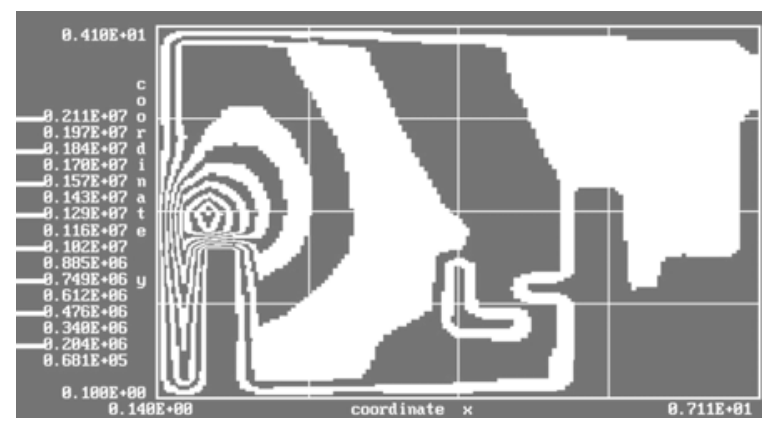

Fig. 3. Concentration field of negative air ions in the room (before reengineering)

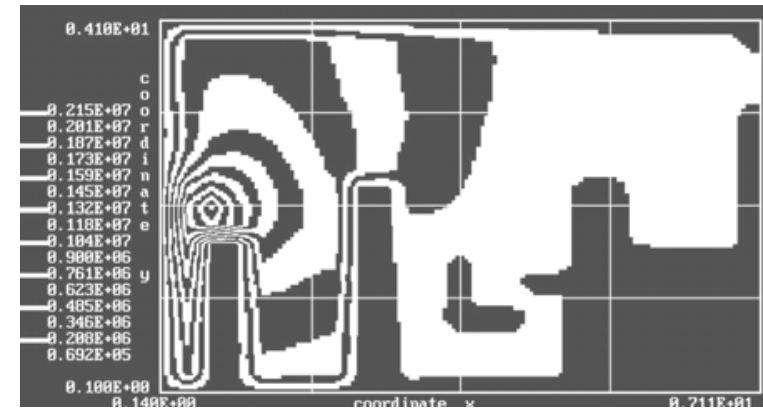

Fig. 4. Concentration field of negative air ions in the room (after reengineering)

As shown in Fig. 3 and Fig. 4, the negative ions concentration in the area of the employee respiratory organs (the position over the chair) for the first variant is about $0.032 \times 10^{12}$ particles $/ \mathrm{m}^{3}$, and after reengineering of the order $0.015 \times 10^{12}$ particles $/ \mathrm{m}^{3}$. That is, the concentration has decreased in 2 times, due to the influence of the installed equipment (Fig. 2, pos. 7) on the formation of air ions concentration field. For the solution of the problem on the basis of the developed CFD model it took about 1 minute of computer time.

The second model. On the basis of the second model calculations were performed to evaluate negative ions concentration in the office premises with volume $62 \mathrm{~m}^{3}$. It should be noted that this «clean volume» of the premises without furniture and other objects. Indoor occurs emission of positive ions in a quantity $22 \times 10^{3}$ particles/s. There is an air, which flows into the premises and contain dust in a quantity $6 \times 10^{3}$ particles $/ \mathrm{m}^{3}$; positive ions in a quantity $10^{4}$ particles $/ \mathrm{m}^{3}$, and negative ions in a quantity $2 \times 10^{3}$ particles $/ \mathrm{m}^{3}$. Ionizer works indoor. The computation is performed for the intensity of the negative ions emission from the ionizer in a quantity $9 \times 10^{7}$ particles/s (the first variant of emission) and $12 \times 10^{7}$ particles/s (the second variant of emission). As a result of calculation negative ions concentration was $0.029 \times 10^{12}$ particles $/ \mathrm{m}^{3}$ for the first variant of emission and $0.040 \times 10^{12}$ particles $/ \mathrm{m}^{3}$ for the second variant of emission. Time of computation is about one second.

\section{Originality and practical value}

The complex of numerical models for computation the air ions concentration in the premises was developed. 2D CFD model, which is based on the use of aerodynamics, electrostatics and mass transport equations, allows taking into account the basic physical factors determining the formation of air ions concentration fields in the premises and work areas. CFD model allows calculating air ions concentration field in premises and working areas at artificial air ionization with taking into account the installed equipment, and given the location of ionizers.

Developed balance model allows calculating quickly the air ions concentration in the premises at artificial air ionization. Also, this model allows take into account the impulse regime of ionizer operation.

\section{Conclusions}

The article contains numerical simulation results of air ion regime in office premises with artificial air ionization. Calculated ions concentration field in the room is presented in the form of isolines. To solve the problem on the basis of the de- 
veloped CFD model took about a minute of computer time. The numerical balance model allows calculating quickly the air ions concentration in the premises. Calculation using the balance model takes about one second of computer time.

\section{LIST OF REFERENCES LINKS}

1. Беляев, Н. Н. Защита зданий от проникновения в них опасных веществ : монография / Н. Н. Беляев, Е. Ю. Гунько, Н. В. Расточило. Днепропетровск : Акцент ПП, 2014. - 136 с.

2. Беляев, Н. Н. Комплекс численных моделей для расчета концентрации аэроионов в помещениях / Н. Н. Беляев, С. Г. Цыганкова // Наука та прогрес транспорту. - 2016. - № 1 (61). C. 30-38. doi:10.15802/stp2016/60947.

3. Беляев, Н. Н. Оценка аэроионного режима в рабочих зонах на базе CFD-модели / Н. Н. Беляев, С. Г. Цыганкова // Зб. наук. пр. НГУ. - Дніпропетровськ, 2015. - № 46. C. $168-173$.

4. Беляев, Н. Н. Расчет аэроионного режима в помещении и в рабочей зоне на базе численной модели / Н. Н. Беляев, С. Г. Цыганкова // Зб. наук. пр. НГУ. - Дніпропетровськ, 2015. № 47. - С. 137-143.

5. Визначення та прогнозування динаміки зміни аероіонного складу повітря виробничих приміщень / В. А. Глива, В. І. Клапченко, С. М. Пономаренко [та ін.] // Вісн. нац. техн. ун-ту України «Київський політехн. ін-т». Серія: «Гірництво». - Київ, 2010. - Вип. 19. C. $161-168$.

6. Деякі аспекти забезпечення нормативного аероіонного режиму робочого середовища приміщень спеціального призначення МНС України / І. О. Толкунов, В. В. Маринюк, I. I. Попов, В. В. Пономар // Проблеми надзвичайних ситуацій : зб. наук. пр. / Нац. ун-т цив. захисту України. - Харків, 2008. - № 8. C. 198-206.

7. Запорожець, О. I. Нормування аероіонного складу повітря робочих приміщень та основні напрями його вдосконалення / О. I. Запорожець, В. А. Глива, О. В. Сидоров // Вісн. нац. авіац. ун-ту. - 2011. - № 1. - С. 139-143.

8. Запорожець, О. І. Принципи моделювання динаміки аероіонного складу повітря у приміщеннях / О. І. Запорожець, В. А. Глива, О. В. Сидоров // Вісн. нац. авіац. ун-ту. -2011. - № 2. - C. 120-124.

9. Левченко, Л. О. Тривимірне моделювання просторових розподілів концентрацій аероіонів у повітрі приміщень / Л. О. Левченко,
В. А. Глива, О. В. Сидоров // Управління розвитком складних систем : зб. наук. пр. / Київ. нац. ун-т буд-ва і архіт. - Київ, 2012. - № 1. C. $198-206$.

10. Моделирование распределения концентрации ионов вблизи ионизатора / В. Е. Бахрушин, М. А. Игнахина, Д. В. Вертинский, А. Ю. Евсюков // Складні системи та процеси. - 2002. № 1. - С. 30-36.

11. Толкунов, І. О. Біполярна іонізація повітряного середовища приміщень функціональних підрозділів мобільного госпіталю МНС / I. О. Толкунов // Проблеми надзвичайних ситуацій : зб. наук. пр. / Нац. ун-т цив. захисту України. Харків, 2014. - Вип. 14. - С. 161-170.

12. Толкунов, І. О. Моделювання процесів формування полів концентрації аероіонів у повітряному середовищі приміщень спеціального призначення МНС України / I. О. Толкунов, I. I. Попов // Проблеми надзвичайних ситуацій : зб. наук. пр. / Нац. ун-т цив. захисту України. - Харків, 2010. - Вип. 12. - С. 175-184.

13. Толкунов, И. А. Теоретическое исследование процессов переноса аэроионов в потоках воздуха в помещениях специального назначения МЧС Украины / И. А. Толкунов, И. И. Попов, В. В. Барбашин // Проблеми надзвичайних ситуацій : зб. наук. пр. / Нац. ун-т цив. захисту України. - Харків, 2010. - Вип. 11. C. $137-145$.

14. Aerosol removal by unipolar ionization in indoor environments / Y. S. Mayya, B. K. Sapra, A. Khan, F. Sunny // J. of Aerosol Science. 2004. - Vol. 35. - P. 923-941. doi: 10.1016/j.jaerosci.2004.03.001.

15. Air ion behavior in ventilated rooms / L. A. Fletcher, C. J. Noakes, P. A. Sleigh [et al.] // Indoor and Built Environment. - 2008. - Vol. 17, № 2. P. 173-182. doi: 10.1177/1420326x08089622.

16. Drexler, P. Numerical modeling of accuracy of air ion field measurement / P. Drexler, P. Fiala, K. Bartusek // J. of Electrical Engineering. - 2006. - Vol. 57, № 8/S - P. 62-65.

17. Murakami, S. Computational wind engineering/ S. Murakami // J. of Wind Engineering and Industrial Aerodynamics. - 1990. - Vol. 36, pt. 1. P. 517-538. doi:10.1016/0167-6105(90)90335-A.

18. Noakes, C. J. Modelling the air cleaning performance of negative air ionisers in ventilated rooms [Electronic resource] / C. J. Noakes, P. A Sleigt, C. Beggs // Proc. of the $10^{\text {th }}$ Intern. Conf. on Air Distribution in Rooms. - Roomvert, 2007 (13.0615.06.2007). - Helsinki, 2007. - Available at: http://eprints.whiterose.ac.uk/7700/1/Noakes_roo 
mvent 07.pdf. - Title from the screen. - Accessed : 17.09.2015.

19. The impact of the air distribution method in ventilated rooms on the aerosol particle dispersion and removal: The experimental approach / A. Jurelionis, L. Gagyte, T. Prasauskas [et al.] // Energy and Buildings. - 2015. - Vol. 86. - P. 305-313. doi: 10.1016/j.enbuild.2014.10.014.

\section{М. М. БІЛЯСВ ${ }^{1 *}$, С. Г. ЦИГАНКОВА ${ }^{2 *}$ \\ ${ }^{1 *}$ Каф. «Гідравліка та водопостачання», Дніпропетровський національний університет залізничного транспорту імені академіка В. Лазаряна, вул. Лазаряна, 2, Дніпропетровськ, Україна, 49010, тел. +38 (056) 3731509 , ел. пошта gidravlika2013@mail.ru, ORCID 0000-0002-1531-7882 \\ ${ }^{2 *}$ Каф. «Водопостачання, водовідведення та гідравліки», Придніпровська державна академія будівництва та архітектури, вул. Чернишевського, 24-а, Дніпропетровськ, Україна, 49600, тел. +38 (050) 69792 18, ел. пошта s-tsygankova@mail.ru, ORCID 0000-0002-9837-3109 \\ КОМПЛЕКС ЧИСЕЛЬНИХ МОДЕЛЕЙ ДЛЯ РОЗРАХУНКУ КОНЦЕНТРАЦІї АЕРОІОНІВ У ПРИМІЩЕННЯХ}

Мета. В статті повинно бути розглянуто створення комплексу чисельних моделей для розрахунку концентраційних полів аероіонів у приміщеннях різного призначення та в робочих зонах. Розроблений комплекс повинен враховувати основні фізичні фактори, що впливають на процес формування концентраційного поля аероіонів. Тобто: аеродинаміку повітряних струменів у приміщенні, наявність меблів, обладнання, розміщення вентиляційних отворів, режиму вентиляції, розташування джерел іонізації, перенесення іонів під дією електричного поля, інші фактори, що визначають інтенсивність та форму концентраційного поля аероіонів. Крім того, комплекс чисельних моделей повинен забезпечити проведення експрес-розрахунку концентрації аероіонів у приміщенні, який дозволяв би швидкий перебір можливих варіантів та можливість «укрупненої» оцінки концентрації аероіонів у приміщенні. Методика. Розроблено комплекс чисельних моделей для розрахунку аероіонного режиму в приміщеннях. Чисельна CFD-модель заснована на застосуванні рівнянь аеродинаміки, електростатики і масопереносу та дозволяє враховувати вплив потоків повітря, викликаних роботою вентиляції, дифузії, вплив електричного поля, а також взаємодію іонів різної полярності один із одним та з частинками пилу. Запропонована балансова модель розрахунку аероіонного режиму в приміщеннях дозволяє оперативно розраховувати концентраційне поле аероіонів із урахуванням імпульсного режиму роботи іонізаторів. Результати. Отримано розрахункові дані, на основі яких можна оцінити концентрацію аероіонів у будь-якому місці приміщення зі штучною іонізацією повітря. Наведено приклад розрахунку концентрації негативних іонів на базі чисельної CFD-моделі в приміщенні 3 реінжиніринговими перетвореннями. На базі розробленої балансової моделі розрахована концентрація аероіонів в об'ємі приміщення. Наукова новизна. Представлені результати розрахунку аероіонного режиму в приміщенні на базі чисельної 2D CFD-моделі та балансової моделі. Практична значимість. Розроблені балансова та чисельні CFD-моделі для розрахунку аероіонного режиму дозволяють розраховувати концентрацію аероіонів у приміщеннях в умовах штучної іонізації повітря з урахуванням основних фізичних факторів, що визначають формування концентраційних полів аероіонів.

Ключові слова: аероіонний режим; концентраційне поле аероіонів; штучна іонізація; CFD-модель; балансова модель

\section{Н. Н. БЕЛЯЕВ ${ }^{1 *}$, С. Г. ЦЫГАНКОВА ${ }^{2 *}$}

\footnotetext{
${ }^{1 *}$ Каф. «Гидравлика и водоснабжение», Днепропетровский национальный университет железнодорожного транспорта имени академика В. Лазаряна, ул. Лазаряна, 2, Днепропетровск, Украина, 49010, тел. +38 (056) 3731509 , эл. почта gidravlika2013@mail.ru, ORCID 0000-0002-1531-7882

${ }^{2 *}$ Каф. «Водоснабжение, водоотведение и гидравлика», Приднепровская государственная академия строительства и архитектуры, ул. Чернышевского, 24-а, Днепропетровск, Украина, 49600, тел. +38 (050) 69792 18, эл. почта s-tsygankova@mail.ru, ORCID 0000-0002-9837-3109
} 


\section{КОМПЛЕКС ЧИСЛЕННЫХ МОДЕЛЕЙ ДЛЯ РАСЧЕТА КОНЦЕНТРАЦИИ АЭРОИОНОВ В ПОМЕЩЕНИЯХ}

Цель. В статье должен быть рассмотрен вопрос создания комплекса численных моделей для расчета концентрационных полей аэроионов в помещениях различного назначения и в рабочих зонах. Разработанный комплекс должен учитывать основные физические факторы, влияющие на процесс формирования концентрационного поля аэроионов. То есть: аэродинамику воздушных струй в помещении, наличие мебели, оборудования, размещения вентиляционных отверстий, режима вентиляции, местоположения источников ионизации, переноса ионов под действием электрического поля, других факторов, определяющих интенсивность и форму концентрационного поля аэроионов. Кроме того, комплекс численных моделей должен обеспечить проведение экспресс-расчета концентрации аэроионов в помещении, позволяющего быстрый перебор возможных вариантов и дающего возможность «укрупненной» оценки концентрации аэроионов в помещении. Методика. Разработан комплекс численных моделей для расчета аэроионного режима в помещениях. Численная CFD-модель основана на применении уравнений аэродинамики, электростатики, массопереноса и позволяет учитывать влияние потоков воздуха, вызванных работой вентиляции, диффузии, воздействия электрического поля, а также взаимодействие ионов различной полярности друг с другом и с частицами пыли. Предложенная балансовая модель расчета аэроионного режима в помещениях позволяет оперативно рассчитывать концентрационное поле аэроионов с учетом импульсного режима работы ионизаторов. Результаты. Получены расчетные данные, на основании которых можно оценить концентрацию аэроионов в любом месте помещения с искусственной ионизацией воздуха. Приведен пример расчета концентрации отрицательных ионов на базе численной CFD-модели в помещении c реинжиниринговыми преобразованиями. На базе разработанной балансовой модели рассчитана концентрация аэроионов в объеме помещения. Научная новизна. Представлены результаты расчета аэроионного режима в помещении на базе численной 2D CFD-модели и балансовой модели. Практическая значимость. Разработанные балансовая и численные CFD-модели для расчета аэроионного режима позволяют рассчитывать концентрацию аэроионов в помещениях в условиях искусственной ионизации воздуха с учетом основных физических факторов, определяющих формирование концентрационных полей аэроионов.

Ключевые слова: аэроионный режим; концентрационное поле аероионов; искусственная ионизация; CFD-модель; балансовая модель

\section{REFERENCES}

1. Belyayev N.N., Gunko Ye.Yu., Rastochilo N.V. Zashchita zdaniy ot proniknoveniya $v$ nikh opasnykh veshchestv [Protection of building from penetration of hazardous substances]. Dnipropetrovsk, Aktsent PP Publ., 2014. 136 p.

2. Belyayev N.N., Tsygankova S.G. Kompleks chislennykh modeley dlya rascheta kontsentratsii aeroionov $\mathrm{v}$ pomeshcheniyakh [Complex of numerical models for computation of air ion concentration in premises]. Nauka ta prohres transportu - Science and Transport Progress, 2016, no. 1 (61), pp. 30-38. doi:10.15802/stp2016/60947.

3. Belyayev N.N., Tsygankova S.G. Otsenka aeroionnogo rezhima v rabochikh zonakh na baze CFD modeli [Evaluation of air ion regime in work areas on the basis of CFD models]. Zbirnyk naukovykh prats Natsionalnoho hirnychoho universytetu - Bulletin of the National Mining University, 2015, no. 46, pp. 168-173.

4. Belyayev N.N., Tsygankova S.G. Raschet aeroionnogo rezhima v pomeshchenii i v rabochey zone na baze chislennoy modeli [Calculation of air ion regime in the premises and work area on the basis of a numerical model]. Zbirnyk naukovykh prats Natsionalnoho hirnychoho universytetu - Bulletin of the National Mining University, 2015, no. 47, pp. 137-143.

5. Hlyva V.A., Klapchenko V.I., Ponomarenko S.M. et al. Vyznachennia ta prohnozuvannia dynamiky zminy aeroionnoho skladu povitria vyrobnychykh prymishchen [Determination and prediction of the ionic air composition change dynamics in industrial premises]. Visnyk natsionalnoho tekhnichnoho universytetu Ukrainy «Kyivskyi politekhnichnyi instytut». Seriia «Hirnytstvo» [Bulletin of Ukrainian National Technical University «Kyiv Polytechnic Institute»], 2010, issue 19, pp. 161-168.

6. Tolkunov I.O., Maryniuk V.V., Popov I.I., Ponomar V.V. Deiaki aspekty zabezpechennia normatyvnoho aeroionnoho rezhymu robochoho seredovyshcha prymishchen spetsialnoho pryznachennia MNS Ukrainy [Some aspects of the regulatory ionic regime in working environment of the special purpose premises of the 
Ukrainian Ministry of Emergencies]. Problemy nadzvychainykh sytuatsii [Problems of Emergencies], 2008, issue 8, pp. 198-206.

7. Zaporozhets O.I., Hlyva V.A. Sydorov, O.V. Normuvannia aeroionnoho skladu povitria robochykh prymishchen ta osnovni napriamy yoho vdoskonalennia [The standardization of the ionic air composition in work premises and main directions of its improvement]. Visnyk natsionalnoho aviatsiinoho universytetu - Bulletin of National Aviation University, 2011, no. 1, pp. 139-143.

8. Zaporozhets O.I., Hlyva V.A. Sydorov, O.V. Pryntsypy modeliuvannia dynamiky aeroionnoho skladu povitria u prymishchenniakh [The principles of modeling the ionic air composition in premises]. Visnyk natsionalnoho aviatsiinoho universytetu - Bulletin of National Aviation University, 2011, no. 2, pp. 120-124.

9. Levchenko L.O., Hlyva V.A. Sydorov, O.V. Tryvymirne modeliuvannia prostorovykh rozpodiliv kontsentratsii aeroioniv u povitri prymishchen [Three-dimensional modeling of spatial distributions for air ions concentrations in the air]. Upravlinnia rozvytkom skladnykh system - Managing the Development of Complex Systems, 2012, no. 1, pp. 198-206.

10. Bakhrushin V.Ye., Ignakhina M.A., Vertinskiy D.V., Yevsyukov A.Yu. Modelirovaniye raspredeleniya kontsentratsii ionov vblizi ionizatora [Simulation of distributing concentration of ions nearly ionizator]. Skladni sistemy ta protsesy - Complex Systems and Processes, 2002, no. 1, pp. 30-36.

11. Tolkunov I.A. Bipoliarna ionizatsiia povitrianoho seredovyshcha prymishchen funktsionalnykh pidrozdiliv mobilnoho hospitaliu MNS [Bipolar ionization of air environment of functional units premises of the mobile hospital of the Ministry of Emergencies]. Problemy nadzvychainykh sytuatsii [Problems of Emergencies], 2014, issue 14, pp. 161-170.

12. Tolkunov I.O., Popov I.I. Modeliuvannia protsesiv formuvannia poliv kontsentratsii aeroioniv u povitrianomu seredovyshchi prymishchen spetsialnoho pryznachennia MNS Ukrainy [Simulation of the ions concentration fields formation in the air space of the special purpose premises of the Ukrainian Ministry of Emergencies]. Problemy nadzvychainykh sytuatsii [Problems of Emergencies], 2010, issue 12, pp. 175-184.

13. Tolkunov I.A., Popov I.I., Barbashin V.V. Teoreticheskoye issledovaniye protsessov perenosa aeroionov $\mathrm{v}$ potokakh vozdukha $\mathrm{v}$ pomeshcheniyakh spetsialnogo naznacheniya MChS Ukrainy [Theoretical study of the ions transport processes in the air flows in the special purpose premises of the Ukrainian Ministry of Emergencies]. Problemy nadzvychainykh sytuatsii [Problems of Emergencies], 2010, issue 11, pp. 137-145.

14. Mayya Y.S., Sapra B.K., Khan A., Sunny F. Aerosol removal by unipolar ionization in indoor environments. Journal of Aerosol Science, 2004, vol. 35, pp. 923-941. doi: 10.1016/j.jaerosci.2004.03.001.

15. Fletcher L.A., Noakes C.J., Sleigh P.A. Air ion behavior in ventilated rooms. Indoor and Built Environment, 2008, vol. 17, no. 2, pp. 173-182. doi: 10.1177/1420326x08089622.

16. Drexler P., Fiala P., Bartusek K. Numerical modeling of accuracy of air ion field measurement. Journal of Electrical Engineering, 2006, vol. 57, no. 8/S, pp. 62-65.

17. Murakami S. Computational wind engineering. Journal of Wind Engineering and Industrial Aerodynamics, 1990, vol. 36, part 1, pp. 517-538. doi:10.1016/0167-6105(90)90335-A.

18. Noakes C.J., Sleigt P.A, Beggs C. Modelling the air cleaning performance of negative air ionisers in ventilated room. Proc. of the $10^{\text {th }}$ Intern. Conf. on Air Distribution in Rooms. Roomvert, 2007. Available at: http://eprints.whiterose.ac.uk/7700/1/Noakes_roomvent_07.pdf (Accessed 17 September 2015).

19. Jurelionis A., Gagyte L., Prasauskas T., Čiužas D., Krugly E., Šeduikyte L., Martuzevičius D. The impact of the air distribution method in ventilated rooms on the aerosol particle dispersion and removal: The experimental approach. Energy and Buildings, 2015, vol. 86, pp. 305-313. doi: 10.1016/j.enbuild.2014.10.014.

Prof. V. M. Derevyanko, D. Sc. (Tech); Prof. V. B. Petrenko, D. Sc. (Tech) recommended this article to be published

Received: Nov. 29, 2015

Accepted: Feb. 09, 2016 